\title{
Preliminary study of natural cross-fertilization in Mung bean, Phaseolus aureus RoxB.
}

\section{H. A. VAN RHEENEN}

Formerly Agricultural Research Station, Manokwari, West Irian (West New Guinea)

\section{Introduction}

The mung bean (Malayan: katjang idju) belongs to the Papilionaceae family. The flowers are $11 / 2$ to $2 \mathrm{~cm}$ long. The stamens and pistil are enclosed in the yellowgreen coloured keel and the flowers seem to be adapted to self-pollination.

As impurities were frequently observed in the varieties maintained in the collection at Manokwari and natural cross-fertilization might be expected to be their main origin, a preliminary investigation was carried out during the years 1961 and 1962.

\section{Material and methods}

\subsection{Experimental design}

Two plots were used, one of $8 \times 5 \mathrm{~m}^{2}$ and another of $7 \times 4 \mathrm{~m}^{2}$. The seed was sown at a spacing of $50 \times 50 \mathrm{~cm}$, ca. 5 per plant hole, and the varieties alternated as is indicated in the following figure:

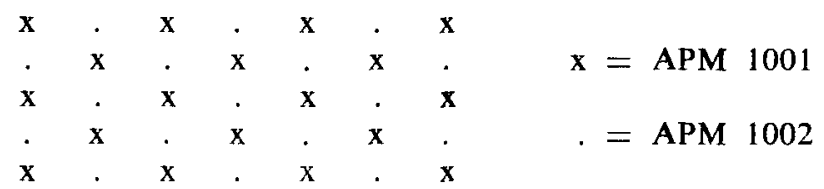

The stands were thinned out to one piant a piece shortly before the beginning of flowering; the dates of sowing and harvesting were 12th January and 22nd March 1962 respectively.

\subsection{Selection of varieties}

The varieties selected for the study were APM 1001 and APM 1002 which among other things differ in hypocotyl colour; APM 1001 has a green and APM 1002 a red hypocotyl, while the $F_{1}$ is again red in colour. Segregation figures of the $F_{2}$ obtained by natural self-pollination are represented in TABLE 1.

The hypocotyl colour appears to be based on ont single gene, red being dominant over green.

\subsection{Determination of cross-fertilization}

The varieties were harvested separately, the only plants taken being those that were still surrounded by four of the other variety at the $50 \mathrm{~cm}$ distance. Ten times 100 seeds of the variety APM 1001 of each plot were laid on moistened filter paper in petri dishes and after germination the seedlings with red and green hypocotyls were counted separately.

Received for publication 10th March, 1964. 
PRELIMINARY STUDY OF NATURAL CROSS-FERTILIzation IN MUNG BEAN; P. AUREUS ROXB.

TABle 1. F2-segregation figures after crossing and one generation of natural self-pollination

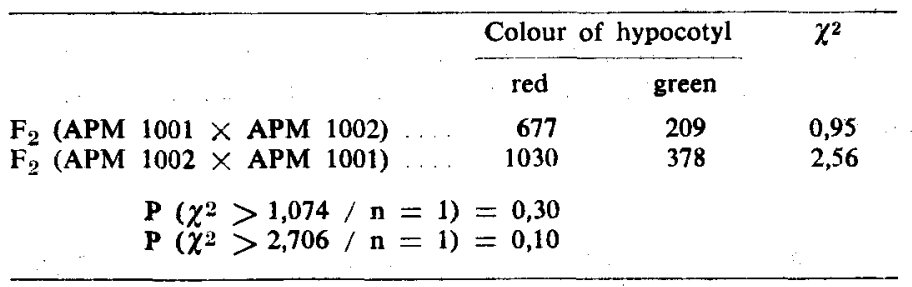

\section{Results}

The results of the countings are represented in TABLE 2.

TABLE 2. Number of seedlings with red and green hypocotyl

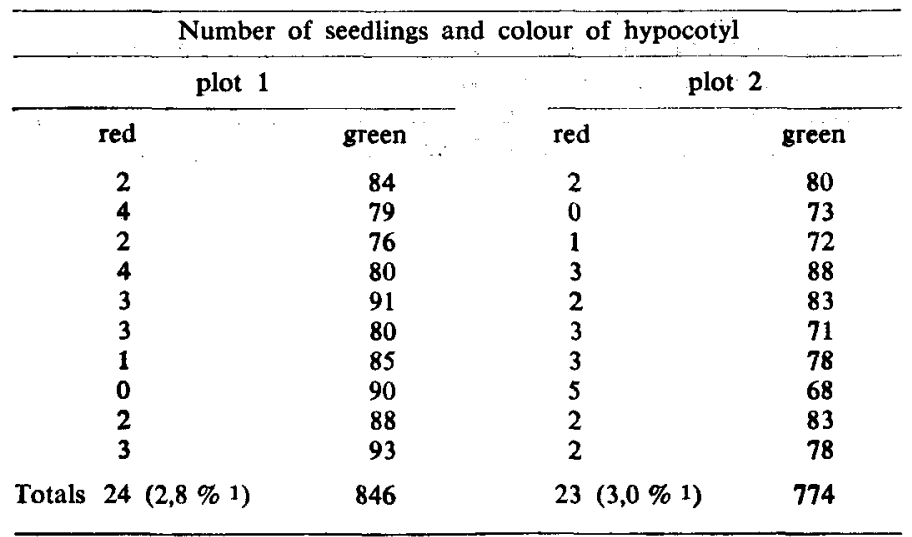

1 Cross-fertilization

\section{Discussion}

To determine the real degree of cross-fertilization an isolated plot with one central plant of the variety with the recessive character surrounded by plants of the variety with the dominant character may be used as design.

In Java, BolHuIs (1940) found that white-flowering soya-bean plants of two different varieties surrounded by purple-flowering plants showed 1,66 and $0,07 \%$ of natural cross-fertilization in their offspring in 1937. In the latter case, a percentage of $0,20 \%$ was found in 1938. With groundnuts sown in alternate rows in the dry monsoon of 1939 the same author found 1,$9 ; 1,4$ and $2,2 \%$ of natural cross-fertilization in his first experiment, in an experiment sown later only $0,8 \%$. In the same experiment repeated in the next wet monsoon the percentages, however, were much lower, i.e. 0,2 and $0,1 \%$. The time of sowing, therefore, may have a remarkable influence on the amount of natural cross-fertilization.

Plants surrounded entirely by those of the variety with the dominant gene might give higher percentages of natural cross-fertilization. ROBERTs a.o. (1961) arranged his rice plants to a pattern in which each plant at a certain distance met an equal number 
PRELIMINARY STUDY OF NATURAL CROSS-FERTILIzATION IN MUNG BEAN, P. AUREUS ROXB.

of plants belonging to the recessive or the dominant variety, and he assumed the real degree of cross-fertilization to be two times the observed cross-fertilization measured as the percentage of dominant phenotypes in the progeny of the recessive variety.

Here the percentage of real natural cross-fertilization may be assumed to be about $4-5 \%$, and to keep the collection varieties in pure condition some discard rows all around the plots are advisable.

\section{ACKNOWLEDGEMENT}

Thanks are due to Ir. G. G. BoLHuIs of State Agricultural University, Wageningen, Netherlands, for his comments on the manuscript.

\section{REFERENCES}

BolmuIs, G. G.

RoBerts, E. H. a.o.
1940 Natuurlijke kruisbestuiving bij kedelee. (Natural crossing in soybeans and the results of experiments on this subject made in Java). Landbouw. 16, 119-128.

1951 Natuurlijke bastaardering bij de aardnoot (Arachis hypogaea). Landbk. Tijdschr. 63, 447-455.

1961 Estimation of percentage natural cross-pollination: Experiments on rice. Nature, London. 190, No. 4781, $1084-1085$. 